\title{
THE NOVEMBER MEETING IN KNOXVILLE
}

The six hundred fiftieth meeting of the American Mathematical Society was held at the University of Tennessee in Knoxville on Friday and Saturday, November $17-18,1967$. There were 410 registrants including 284 members of the Society.

By invitation of the Committee to Select Hour Speakers for Southeastern Sectional Meetings, there were three invited speakers. Professor A. S. Householder of Oak Ridge National Laboratory and the University of Tennessee was introduced by Professor J. H. Barrett. He spoke on Normed and localization theorems for root of matrices. Professor Bjarni Jonsson of Vanderbilt University, who spoke on Representation of lattices, was introduced by Professor A. T. Brauer. Professor J. W. Neuberger introduced Professor Pasquale Porcelli of Louisiana State University who spoke on Survey of decomposition theory for rings of operators.

The sessions for contributed papers were chaired by Professors Erik Hemmingsen, Clayton V. Aucoin, Charles McArthur, Paul E. Waltman, John Bryant, Trevor Evans, Tomlinson Fort and Bernard Fusaro.

A beer party was held at the Farragut Hotel Friday evening from 8:00 to 11:30 P.M. for the members of the Society and their guests.

Knoxville, Tennessee

O. G. HARROLD

Associate Secretary 